\title{
1910/1911 Tarihli İlkokul Müfettişlerinin Görevlerine Dair Yönerge’nin Günümüz Eğitim Teftişi Uygulamaları ile Karşılaştırılması *
}

\author{
Mehmet Emin USTA** \\ Fatma ÖZMEN***
}

Öz: Bu çalışmanın amacı, Osmanlı Döneminde ve günümüz Türkiye’sinde yapılan eğitim teftişine ilişkin kuralları karşılaştırmalı olarak ortaya koymaktır. Bu kapsamda İstanbul Üniversitesi Kitaplığı arşivinde bulunan 1326 tarihli “Mekâtib-İ İbtidâiye Müfettişlerinin Vezâifine Dâir Talimât" transkribe edilmiştir. Yapılan bu işlemin ardından söz konusu belgedeki eğitim teftişi uygulamaları günümüz eğitim teftişi uygulamaları ile karşılaştırılmıştır. Genel olarak ilgili talimata bakıldığında müfettişlerin görevlerinin tahkikat (soruşturma), teftişat (denetim) ve vasâyâ icrası (halka öğüt verme) olduğu görülmektedir. Günümüzde geçerli 02/12/2016 tarih ve 6764 sayılı Millî Eğitim Bakanlığının Teşkilat ve Görevleri Hakkında Kanun Hükmünde Kararname hükümlerine göre ise Maarif Müfettişleri’nin görevleri rehberlik, işbaşında yetiştirme, teftiş, değerlendirme, inceleme, araştırma ve soruşturma olarak belirlenmiştir. İki dönem mevzuatı karşılaştırıldığında soruşturma ve teftiş işlerinin hala müfettişlerin asli görev tanımı içinde bulunduğu; halkı aydınlatma, işbaşında yetiştirme, değerlendirme, inceleme, araştırma açılarından ise farklılıklar meydana geldiği görülmektedir.

Anahtar Sözcükler: Eğitim Teftişi, Müfettişler, Osmanlı Dönemi, Düzenlemeler

\footnotetext{
* Söz konusu yönerge, Fırat Üniversitesi Bilimsel Araştırma Projeleri Koordinasyon Birimi’nce desteklenen ve Prof. Dr. Fatma ÖZMEN'in yürütücü olduğu, Prof. Dr. Erdal Açıkses, Yrd. Doç. Dr. Mehmet Emin USTA, Yrd. Doç. Dr. Sıtkı ULUERLER'in araştırmacı olduğu 1845 nolu, "Meşrutiyetin İlanından, Cumhuriyet Dönemine, Osmanlı Devleti'nde Eğitim Denetimi (1876-1923)” adlı proje kapsamında elde edilmiş ve çevirisi yapıllmıştır. ** Yrd. Doç. Dr. Harran Üniversitesi Eğitim Fakültesi Öğretim Üyesi. e-mail: mehmeteminusta@ gmail. *** Prof. Dr. Emekli Öğretim Üyesi. e-mail: ftm_ozmen@yahoo.com
} 


\title{
A Comparison of Legislation Document about Primary School Inspectors' Duties Dated 1910/1911 with Today's Supervisory regulations
}

\begin{abstract}
Aim of this study is to compare patterns and rules of educational supervison realized in Ottoman period and in Turkish Republic. In this regard, the directives for primary school inspectors, dated according to old Ottoman calendar as 1326 (A.D. 1910-1911) dated the document named as "The Directives Related to the Jobs of Primary School Inspectors", which was held from the Library of Istanbul University archives, was transcribed. Then, the applications of those directives were compared with the current regulations towards supervision. From a broader perspective, it can be concluded that Ottoman time duties were investigation, inspection, and advices to the people. When it comes to current practices about supervision in education, which are dependent on regulation dated 02/12/2016 and issue number 6764, roles of supervisors are guidance, in-service training, inspection, evaluation, investigation, inquisition, and research. When the two legislations are compared, investigations and inspections are still in the main task of the supervisors; it is seen that there are differences in terms of public illumination, in-service training, evaluation, examination and research. Interrogation and inspection continue to exist in the duties of inspectors. Contrarily, enlightenment of public, on-the-job learning, assessment, and investigation are differing duties of supervisors with the old ones.
\end{abstract}

Keywords: Educational Supervision, Supervisors, Ottoman Period, Regulations 


\section{Giriş}

Sanayi devrimi koşullarına bağlı olarak kurulan ve sadece soyluları değil, toplumun tüm kesimlerini eğitmeyi amaç edinen modern okul, etkililik açısından hep eleştirilmiştir. Kendisinden isteneni, istenen düzeyde gerçekleştirmesi gereken okulun etkililiğini arttırmak için en çok yönetimin denetim işlevi kullanılmıştır. Bu sayede okul, istenen düzeye yakınlaştırılmış, sapmalar engellenmeye çalışılmış ve eğitim sürecinin geliştirilmesi hedeflenmiştir.

Bütün örgütler başarmak hedefiyle kurulurlar. Başarmanın temel koşulu, iyi bir yönetim sistemi oluşturabilmektir. Bir sistem dâhilinde çalışan örgütlerin başarılı olması, amaçlar çerçevesinde, iyi bir planlama, istihdam, denetim ve yöneltmelerin iyi yapılmasından geçer. Sürecin iyi işleyip işlemediği teftiş aracılığı ile gerçekleşir. Teftiş, düzeltici, iyileştirici önlemlerin alınmasını sağlayan bir işlev de görebilir (Özalp, Koparal ve Berberoğlu, 2000: 132).

Teftiş, bütün örgütlerdeki görevlilerin ilgili yasal düzenlemelere göre görevlerini gereği gibi icra edip etmediklerini, görevlerinde ihmal ve dikkatsizlik gösterip göstermediklerini, kötü bir durum olup olmadığını tespit etmek amacıyla müfettişler ya da denetçiler eliyle yapılan bir gözlem ya da kontrol sürecidir (Taymaz, 2010, 3). Yönetim faaliyetlerinin planlandığı gibi yürüyüp yürümediğinin saptanması için gerekli yönetim işlevi teftiştir. Teftiş, önceden belirlenmiş örgütsel amaçlara ve hazırlanmış planlara dayalı olarak yapılmalı, örgüt içinde yapılan işi kapsamalıdır. İlgili faaliyetlerin ihtiyaçlarına karşılık gelmeli, değişimin kaçınılmaz bir sonucu olarak örgütler, amaçlarına gerçekleştirme sürecinde esnekliği benimsemeli ve teftiş, bu esneklik dikkate alınarak yapılmalıdır. Yapılacak teftiş, örgütteki yöneticilerin düzeltici önlemler almalarını sağlayıcı nitelikte, örgüte uygun ve ekonomik olmalıdır. Diğer bir deyişle, zaman, maliyet, ve uygulanabilirlik bakımından 
olabildiğince işlevsel olmalıdır. Yapılan teftişte tarafsız olmalı, duygusallıktan kaçınılmalıdır. Sadece sapmaların belirlenmesi değil, sapmaların önlenebilmesi için de düzeltici önlemlerin alınmasını sağlamaya dönük olmalı, üst yönetim dahil, tüm örgütü kapsamalıdır. Süreç, sık sık gözden geçirilmeli, teftişin nasıl işlediği, tüm yöneticilerce anlaşılabilir olmalıdır (Özalp, Timur, Koçel vd.,1996: 86).

Teftişin düzeyi ve genel durumu şu yöntemlerle ortaya konulabilir (Başaran, 2000:138; Hesapçığlu, 1994:279):

1. Standardizasyon: Örgütün amaçlarına ulaşıp ulaşmadığını ölçen sabit ölçütlerin olması demektir. Bu kendi içinde iki aşamalıdır. Birincisi, amaçlara ulaşmak için gerekli olan performans düzeyinin saptanmasıdır. İkincisi, yapılması gereken işin ne kadarının çalışanlarca yapılabileceğidir.

2. Ölçme: Örgütte ortaya konan performansın önceden belirlenen standarda ne oranda uyduğunun ölçülmesidir. Bunun için ölçme araçlarına ihtiyaç vardır.

3. Düzeltme: Amaca ulaşmayan çabaların amaca yöneltilmesine denir. Düzeltmenin yapılabilmesi için sapmanın iyi teşhis edilmesi gerekir. Bu aşamada çalışanlar ile uzmanların işbirliğine ihtiyaç vardır.

4. Karşılaştırma: Yapılması gereken iş için ortaya konmuş ölçütler ile yapılan işin karşılaştırılarak aradaki farkın bulunmasıdır.

5. Değerlendirme: Teftiş neticesinde elde edilen bulgulardan hareketle bir yargıya varma sürecidir.

\section{Eğitim Teftişi}

Eğitim teftişinin amacı okul etkililiğini sağlamaktır. Okul etkililiği, okulun belirlenmiş amaçlarını ve bu çerçevede yapmış olduğu planları gerçekleştirme düzeyidir. Eğitim teftişi okul yöneticileri, müfettişler ve diğer üst yöneticiler tarafından yapılır. Eğitim teftişi 
yapılırken katı kural ve görev tanımlarından arındırılarak, eğitim yöneticilerinin kendi yaratıcılıklarını kullanmalarına imkân tanınmalı ve eğitim çalışanlarının değerli olduğu, teftişin bir ekip ruhu gerektirdiği, teftiş elemanın liderlik özelliklerine sahip olmasına, teftiş edilen eğitim çalışanlarının kendilerini kanıtlama ve başarılı olma imkânına sahip olmasına, eğitim teftişinin planlı ve sürekli olması gerektiği hususlarına dikkat edilmelidir (Başaran, 2000: 137).

Eğitim teftişi, eğitim kurumlarının görevlerini yasalar ve ilgili düzenlemeler çerçevesinde ifa ederek, hizmet niteliğinin artmasını sağlamada ciddi bir işlev görmektedir. Kısaca eğitim teftişi, eğitim örgütlerinin uygulama ve davranışlarının mevzuata uygunluğunu kamu adına ve yararına kontrol etme işidir. Çağdaş yönetimlerde, hedef belirlemeyen ve bu hedefleri gerçekleştirmek için bir planlama yapmayan ve uygulama sonuçlarını değerlendirmeyen bir yönetim anlayışından söz edilemez. Üretilen ve gerçekleştirilen hizmetin nitelik kontrolü, alınan dönütler doğrultusunda eksiklik ve yanlışlıkların giderilmesi, amacın gerçekleştirilmesi açısından bir gerekliliktir (http://rdb.meb.gov.tr/www/turk-egitim$\underline{\text { sisteminde-rehberlik-ve-denetimin-tarihsel-gelisimi/icerik/9). }}$.

\section{Osmanlı'da Eğitim Teftişi}

Türk Eğitim Sisteminde teftiş alt sistemine olan ihtiyacın Osmanlı İmparatorluğu yenileşme faaliyetlerinin en etkili olduğu Tanzimat Döneminde hissedilmeye başlandığ anlaşılmaktadır. Tanzimatın ilanını müteakiben, teftiş alt sisteminin ana omurgası oluşturulmuş, sonraki dönemlerde de ilgili hukuki düzenlemelerle günün şartlarına uyarlanmaya çalışılmıştır (Buluç, 2008).

Taymaz'a (2010:19) göre Osmanlı İmparatorluğu'nda eğitim teftişinin tam olarak ne zaman başladığı ve başlangıç döneminde kimlerce yapıldığı tam olarak belli değildir. Bununla birlikte eğitim teftişi içerikli birçok belge bulunmaktadır. Bunlardan bazıları şunlardır 
(Taymaz, 2010; Aydın, 2014; Öz, 2003; Şahin, Elçiçek ve Tösten, 2013: http://rdb.meb.gov.tr/):

-1838: Rüşdiye okullarının eksiklerinin giderilmesi ve bu eksiklerin giderilmesinden sorumlu görevlilerin okulları teftiş etmesi.

-1846: İlkokul (Mekatib-i Sibyaniye) ve ortaokul (Mekatib-i Rüşdiye) teftişinden sorumlu muinlikler oluşturulması.

-1862: İlk defa ilkokul (Mekatib-i Sibyaniye) ve ortaokul (Mekatib-i Rüşdiye) teftişinden sorumlu olanlara müfettiş denmesi.

-1875: İlk defa, teftiş edilecek okullarda teftiş defteri bulundurulması gerektiği ve istenildiğinde bu defterin müfettişlere gösterileceğinin ifade edilmesi.

-1876: Meclis-i Maarif tarafından teftiş ile ilgili bir talimatın yayımlanması.

-1911: Eğitim Bakanlığı Merkez Teşkilatı Yönetmeliği hükümlerine göre merkez hizmetlerinin idare ve teftiş olarak ikiye ayrılması. Ayrıca müfettişlerin orta ve yüksek okul öğretmenleri arasından seçilmesi esasının getirilmesi.

-1912: Hazırlanan bir tüzükte müfettiş-i umumilik ibaresinin yer alması ve “...ülkede bulunan kız ve erkek okulları ile Bakanlığa bağlı diğer kuruluşların öğretim, yönetim işlerini ve onların her birine ait kanun, tüzük, yönetmelik ve karar hükümlerinin tamamıyla uygulanıp uygulanmadığını sürekli olarak teftiş ve bu husustaki izlenimlerini, edinecekleri bilgileri, düşünceleri ile birlikte Bakanlığa bildirmek, sonuçları alıncaya kadar kovuşturmak görevi ile yükümlü ...” olduklarının bu tüzükte yer alması ve böylece eğitim müfettişlerinin görev ve sorumluluklarının bir yandan eğitim işleri diğer yandan soruşturma olduğunun açıkça belirtildiği görülmektedir.

-1913: İlkokul teftişinin ilköğretim müfettişlerince yapılması gerektiği ve ilköğretim müfettişlerinin teftiş, tahkikat ve irşad olarak üç görevlerinin olduğunu belirtilmesi. 
-1914: Eğitim müfettişlerinin kurum teftişinde göz önünde bulunduracakları esasların düzenlendiği “Maarif Müfettişlerinin Vazifelerine Dair Talimatname’nin“ yayımlanması.

\section{Amaç}

Bu araştırma ile 1910/1911 Tarihli İlkokul Müfettişlerinin Görevlerine Dair Yönerge hükümleri ile, günümüzde Yapılan Okul Teftişine ilişkin durumun Karşılaştırılması amaçlanmaktadır. Bu amaçla aşağıdaki sorulara cevap aranmıştır:

1. 1910/1911 Tarihli İlkokul Müfettişlerinin Görevlerine Dair Yönerge'de teftiş ile ilgili hangi hükümler bulunmaktadır?

2. Günümüzde okul teftişi ile ilgili hangi düzenlemeler bulunmaktadır?

3. Osmanlı Dönemi (1910/1911) okul teftişi ile günümüz okul teftişi arasındaki benzerlikler ve farklılıklar nelerdir?

\section{YÖNTEM}

Araştırma Modeli: 1910/1911 Tarihli İlkokul Müfettişlerinin Görevlerine Dair Yönerge'nin Günümüz Okul Teftişi ile Karşılaştırılması adlı bu çalışma, belgesel tarama modelindedir. Tarama modelleri, geçmişte ya da şimdi var olan bir durumu olduğu biçimiyle ortaya koymaya çalışan araştırma modelleridir. Bu modellerde geçmiş olaylara ilişkin olgu temin etme, ilişki kurma ve yargılara varmak amacı ile kanıt toplanır. Bu kanıtlar tarihsel veri kaynaklarıdır. Tarihsel veri kaynakları yazılı ve basılı belgeler olabileceği gibi, ilgili döneme ait kalıntılar da olabilir (Karasar, 1999). Ayrıca çalışmada nitel araştırma yöntemi kullanılmıştır. Nitel araştırma yöntemi gözlem, görüşme ve doküman analizi gibi yöntemlerinin kullanıldığı, algılandığı ve olayların doğal ortamda gerçekçi ve bütüncül bir biçimde ortaya konmasına yönelik bir sürecin izlendiği araştırma türü olarak kabul edilir (Yıldırım ve Şimşek, 2008). 
Verilerin Toplanması: Araştırmanın yapılabilmesi için ilk iş olarak Başbakanlık Arşiv Müdürlüğü’ndeki belgeler taranmış, daha sonra İstanbul Üniversitesi Nadir Eserler Kütüphanesi'ndeki eserler arasında Osmanlı Devleti'nde teftiş konulu çalışmalar incelenmiştir. Nihayet, matbaa basımı yanında çeşitli yazı stilindeki el yazması şeklinde birçok belge elde edilmiştir. Bu belgeler, kendi içlerinde incelenerek, doğrudan eğitim teftişi ile ilgili olanları ayrılmış ve bunların günümüz Türkçesine çevirisi yapılmıştır. Bu süreçte 1326 tarihli "Mekâtib-i İbtidâiye Müfettişlerinin Vezâifine Dâir Talimât” görülerek transkribe edilmiştir. Yapılan bu işlemin ardından söz konusu belgedeki eğitim teftişi uygulamaları günümüz eğitim teftişi uygulamaları ile karşılaştırılmıştır. Adı geçen belgenin aslı Ek 1'de, transkribe edilmiş hali ise aşağıda gösterilmiştir.

(İst. Üniv.6373 Matbu...0001-0002-0003-0004-0005)

Belge Transkribi

Mekâtib-i İbtidâiye Müfettişlerinin Vezâifine Dâir Talimât

İstanbul Matbaa-i Amire 1326 (1910/1911)

İstanbul Üniversitesi Kitaplığ1-123437

Mekâtib-i İbtidâiye Müfettişlerinin Vezâifine Müteallik Talimât

Mekâtib-i ibtidâiye müfettişliklerinin ihdâsında üç maksat gözetilmiştir; tahkîkât, teftîşât, vasâyâ icrası.

Tahkîkât- tahkîkâttan murâd evvlâ; Müfettişler bulunduğu livâyı köy köy gezerek her karyenin aded-i nüfûsuna göre burada mevcut olması lâzım gelen mekteb-i ibtidâiyenin derecesini yani mekteb bir dershâneli mi, iki dershâneli mi, üç dershâneli mi olarak tayin eylemek. Mekâtib-i ibtidâiyenin inşâsına müteallik olan talimâtta bu tahkikin sûret-i icrâsı tasrih olunmuştur. Dört yüz nüfûsu olan bir köyde tahsil-i ibtidâiye müdâvim olacak etfâlın adedi elliyi tecâvüz etmeyeceğinden böyle olan köylerde yapılacak mekteb-i ibtidâiyenin 
yalnız bir dershânesi bulunmak iktizâ eder. Yine bu nisbet gözetilerek nüfûsu dört yüzü mütecâviz olan köylerde mektebin iki dershânesi, sekiz yüzü mütecâviz olan köylerde üç dershânesi bulunacaktır.

Sâniyen; mekteb-i ibtidâiyenin inşasına dâir olan talimatta mevaâdd-1 mahsûsa vardır. 326 senesi bütçe kânununun yirmi yedinci maddasi mûcebince hazineye ait olan arsalar taleb vukuunda Maârif'e terk edileceğinden emlâk-1 umûmiyeden olarak karye dâhilinde mekteb inşâsına elverişli böyle arsalar mevcûd olduğu tahkîk edilerek kazâ encümen-i maârifi marifetiyle hükümetten taleb olunmasına delâlet eylemek.

Sâlisen: İntihâb edilen arsa üzerine talîmât-ı mahsûsasına tevfikan mekteb inşası muâmelâtını ifâ eylemek. Maârif nizamnâmesinin dördüncü maddasi mûcebince mekâtib-i ibtidâiye binalarının inşâsı cemâate âit ve tahsil-i ibtidâiye memûr olanların vezâifine müteallik olan nizamnâme ahkâmına binâen mekteblerin emr-i inşâsı me'mûrîn-i mülkiyeye ve maârif-i ibtidâiye heyetlerine muhavveldir. Bu bâbta (Sh-4) mekâtib-i ibtidâî müfettişinin vazifesi mektebin derecesini ve mahalli tayin ile karyenin tâbi olduğu kazânın kaymakamına rapor vermek ve bu bâbda takibât icrâ ile mutasarrıf ve vâliye ve icâbında Maârif Nezâreti'ne de işi bildirmektir.

Râbian; Mekteblerin talimât-1 mahsûsasına tevfikan inşâ olunmalarına nezâret eylemek.

Hâmisen; Karyelerde evkâf-1 münderise ve âvârız akçeleri ve karyeye âid vâridât-1 husûsiye hakkında tahkikâ ticrâ ederek evkâf-ı münderise talimâtı mûcebince Maârif’e alınması lâzım gelen vâridat-1 vakfiye buldukları halde bunların zaptı için hükûmât-1 mahalliye ihbâr-1 keyfiyet eylemek.

Teftîşât- Mekâtîb-i ibtidâiye müfettişlerinin teftîşâta âit olan vazîfeleleri ber-vech-i âti tadâd edilir. 
Evvelâ; mektebler binâlarına müteallik olan teftîşât; kasaba ve karyelerde mekteb binâlarının kaç kısımdan ve aksâm-1 mektebin nasıl iktizâ edeceği tarîf olunmuş idi. Binâen aleyh mevcûd mekteblerin bu şerâite muvaffak olup almadığı hakkında teftîşât icrâ edilecek ve netice-i teftîşât tavâliye ve Maârif Nezâretine bildirilecektir. Bu teftîşât ile mevcûd mekâtib-i ibtidâiyenin ahvâl-i binâiyeleri hakkında hâsıl olacak ıttıla üzerine memûrin-i âidesince pey-der-pey mekteb binâlarının tevsi ve ıslahı esbâbı istikmâl edilecektir.

Sâniyen; İnâs mektebe müteallik olan teftişât; İnâs mekteb yerlerinde sâbit ve istimâli dâim olan levazımdan ibârettir ki bunlar da esâsen dershânelerde talabenin oturmasına ve ders yapmasına mahsûs olan sıra ve rahleler ile muallim kürsüsü, yazı tahtası gibi seylerdir. Bu bâbda ayrıca bir talimât tebliğ olunmuştur. Mekâtib-i ibtidâiye müfettişleri bu talimât dâiresinde teftiş icrâsiyle her mekteb-i ibtidâide inâs mektebin ne halde bulunduğu ve bunların talimat-1 mezkûreye tevfikan ıslâh ve ikmâli hakkında raporlarını kezâlik vâliye ve maârif nâzırına irsâl edecektir.

Sâlisen; Mühimmât-1 dersiyeye müteallik olan teftişât; Mühimmât-1 dersiyeden maksat her şâkirdin kendi elinde bulunarak muallimin takrîr edeceği dersten istifâde teminine medâr olan ve şâkirdin istimâl ve say-i şahsîsine mahsûs olan levâzımdır.

Kırâ'et kitapları, ders kitapları yazı ve resim ve meşk defterleri. Kalem, mıstara, kurşun kalemi, yazı hokkası, siyah el yazı tahtası, atlas, resim edevâtı vesâire gibi kız çocukları için başkaca iplik, iğne, yüksük, makas, dikiş talimine mahsus kumaş ve emsâli şeylerdir. Bunların envâ1 Maârif Nezâreti Tedrîsat-1 İbtidâiye Müdüriyeti'nce tayin ve fihristi tebliğ olunacaktır. Mekâtib-i ibtidâiye ders kitaplarının intihâbı vilâyet maârif-i ibtidâiye meclislerine âittir.

Mekâtib-i ibtidâiye müfettişleri mühimmât-ı dersiyye hakkında kezâlik teftiş icrâ edecek ve fukarâ etfâlin levâzım-1 dersiyeleri meccanen verilmek üzere listesini vilâyete gönderecektir. 
Râbian; âlât-1 tedrisiyeye müteallik olan teftişât; âlât-1 tedrisiye her dersin talim ve tedrisinde tecrübe ve istimâl edilecek elvâh âletlerdir ki umûm sınıf talebesinin istifâlarına mahsusdur. Mekâtib kırâet levhaları mihsâb, evzân ve ekyâl mecmuası, duvar haritaları, eşyâ koleksiyonları vesaire gibi. Mekâtib-i ibtidâiye için lüzumu olan âlât-1 tedrîsiyenin envâı ve fihristleri Maârif Nezâreti Tedrîsat-1 İbtidâiye Müdüriyeti’nce tertîb edilir. Mekâtib-i ibtidâiye müfettişleri elvâh-1 âlât-1 tedrîsiye hakkında da mütemadiyen teftîşatta bulunarak bunların hüsn-i halde muhâfaza olunmalarına dikkat ve nezâretle mükelleftir. Bu bâbda dahi raporlarını vâliye ve Maârif Nezâreti'ne göndereceklerdir.

Mekteb kütübhâneleri hakkında icrâ edilecek teftîşât; Her mekteb-i ibtidâiyede muallimlerin mütâlaasına ve fukarâ şâkirdânın istifadelerine mahsûs olmak üzere mekteb kütübhâneleri teşkil edilecektir. Mekâtib-i ibtidâiye müfettişlerini bir vazifesi de bu kütübhaneleri teftiş eylemek ve hüsn-i muhafazasına nezâret eylemektir.

Hâmisen; Tedrîsâta müteallik Teftîşât; Mekâtib-i ibtidâiye müfettişleri mekâtib-i ibtidâiyede tedrîsâtın programa inhâ-yı cedîde-i tedrîse muvafik surette cereyân etmesine bilhassa dikkat ve himmet edecekler ve şâkirdânın derece-i istifâdelerini tahkîk eyleyeceklerdir. Bu bâbda mekteb muallimlerine tenbîhât-1 lâzimede bulunacakları gibi derslerin sûret-i idâre ve takrîrine müteallik muallimlere konferanslar vereceklerdir. İkinci bir teftişte tenbîhat dâiresinde hareket edilmediği görüldüğü ve muallimin aczi anlaşıldığı halde hemen vilâyet maârif müfettişine işâr-1 keyfiyet edeceklerdir. Bilumûm mekâtib-i iptidâiyede tedrîsâtın muktezâ-yı meşrûtiyete ve icâbât-ı Osmâniyet'e tevfikan cereyânına pek ziyâde itinâ ile bu husûs-1 mühimmi hiç bir vakit nazar-1 dikkatten dûr tutmayacaklardır. Mekâtib-i ibtidâiyede Meclis-i Kebir-i Maârifin tasvîb etmediği veya men eylediği kitapların tedrisine müsâade etmeyeceklerdir. 
Mektebin ahvâl-i sıhhiyesine müteallik teftîşât; Mekâtib-i ibtidâiyenin husûsât-1 sıhhıyelerini teftiş vazifesi esâsen vâli ve mutasarrıf ve kaymakâm tarafindan me'mûr edilecek etıbbây-1 müfettişeye âittir. Fakat mekâtib-i ibtidâiye müfettişleri dahi bu vazifede müşterektirler. Maârif nezâretinde müteşekkil Hıfzıs-sıhha-i Etfâl Komisyonu tarafından tertîb olunan talîmâta tevfikan bu bâbda dahi icrâ-yı teftişe me'mûrdurlar. Raporlarını mektebin bulunduğu mahallin en büyük mülkiye me'mûruna vereceklerdir. Mekteblerin nezâfetine ve şâkirdânın bu nokta-i nazardan kıyâfetine de nezâret edeceklerdir.

Mekâtib-i Husûsîye’ye (özel okullar) âid Teftişât;

Cemâat mektebleriyle mekâtib-i husûsiyede müfettişlerin icrâ edeceği teftîşât-1 tedrîsât nizâmına ve Osmanlılık şânına tevfikan cereyanına nezâret edeceklerdir. Esnây-1 teftişte buna muhâlif tedrîsatta bulunduğu ve muallimlerin yedinde Maârif Nezâreti ve idâreleri tarafından musaddak şahâdetnâme bulunmadığı müşâhade edecek olursa derhal valiye ve maârif nâzırına beyân-1 keyfiyet edeceklerdir. Maârif Nezâreti'nce tedrîsi men edilen bir kitabın okutturulduğu görülürse derhal vâliye bildirecekler ve kitapları zabteyleyeceklerdir.

İşbu talimâtta tahkîkât kısmına ait olan husûsât-1 nehiyyat (yasak konular) iki aya kadar ikmal edilerek raporlarının birer sureti nezârete bildirilmek lâzımdır.

Vasâyâ; mekâtib-i ibtidâiye müfettişleri kasabâtı ve kurâyı dolaştıkları sırada ahaliye maârif ve mekâtib hakkında vasâyâ-yı (tavsiye) lâzimede bulunacaklardır.

\section{Bulgular}

Yukarıda gösterilen 1910-1911 tarihli “illkokul Müfettişlerin Görevlerine Dair Talimat" adlı belgede ilkokul müfettişlerinin üç gerekçe nedeniyle istihdam edildiği belirtilmektedir. Bunlar; inceleme/soruşturma (tahkikat), teftiş ve tavsiye'dir. İnceleme/soruşturmadan kastedilen şey, müfettişlerin köy köy gezerek söz konusu yerleşim yerlerinde kaç dersliğe ihtiyaç duyulduğunu saptamalarıdır. Buna göre: 
1. İlkokulların inşası hakkında yönetmelik hükümlerine göre dört yüzden az nüfusu olan yerleşim yerlerinde öğrenci sayısı 50'yi geçmeyeceğinden bir derslik; nüfusu dört yüzü geçen yerlerde iki derslik ve nüfusu sekiz yüzü aşan yerlerde üç derslik yapılacaktır.

2. İlkokul inşaatlarına özel çıkarılan emirnamede belirtildiği üzere köylerde okul yapımı için uygun olan arsalar eğitim komisyonu marifetiyle hükümetten talep edilecektir.

3. Müfettişler, seçilen arsa üzerinde okul yapımı için gerekli desteği verecek, inşaatı izleyecek ve okulun derecesini belirledikten sonra kaymakam ya da valiye rapor verecektir. Gerekmesi durumunda Eğitim Bakanlı̆̆ı'na da rapor verilecektir.

4. Müfettişler, okulların yapımı ile ilgili emirlere uygun yapılıp yapılmadığını kontrol edecektir.

5. Müfettişler, köylerde işlevi bitmiş vakıflar ve köye ait diğer gelirler ile ilgili inceleme yapacak, bir gelir bulması durumunda vaziyet yerel yönetime bildirilecektir.

Teftişten kastedilen hususlar şu şekilde açıklanmaktadır:

1. Okul binalarında hangi bölümlerin bulunması gerektiği belirtilecek. Okul binaların bu özelliklere sahip olup olmadığı teftiş edildikten sonra durum Valiliğe ve Eğitim Bakanlığı'na bildirilecektir. Bu işlemi müteakip imkanlar dahilinde, ilkokullar peyderpey onarılacak ve islah edilecektir.

2. Kız okullarında teftiş, bu okullarda bulunması gereken malzemeler olan sıra, rahle, hoca kürsüsü, yazı tahtası vs. bulunup bulunmadığı yönünden yapılacaktır. Daha önce bu konuda yayımlanmış bulunan emirler gereğince müfettiş, kız ilkokullarının ne durumda olduğunu görerek ıslahı için rapor düzenleyecek ve bu 
raporu Valilik ve Bakanlığa sunacaklardır.

3. Teftiş, dersin önem durumuna binaen yapılacak ve öğretmenin anlattığg dersin öğrenciye faydası ve gelişimine katkısı açısından ele alınacaktır. Okullarda bulunması gereken malzemeler okuma kitapları, ders kitapları, yazı ve resimli çalışma kitapları, kalem, yazı cetveli, hokka, siyah tahta, atlas, resim edevatı ile ayrıca kız öğrencilere mahsus olarak iğne, iplik, yüksük, makas, kumaş vb. şeylerdir. Bunlar Eğitim Bakanlığı İlkokul Müdürlüğü tarafından temin edilecektir. Ders kitaplarının seçimi ise il ilköğretim komisyonu tarafından yapılacaktır. İlkokul Müfettişleri bunun üzerine derslerin önemine binaen bir teftiş yapacak ve fakir öğrencilerin listesini ders ihtiyaçları ücretsiz karşılansın diye valiliğe göndereceklerdir.

4. Ders aletlerine dönük olarak gerçekleştirilecek teftiş, her dersin kendi durumuna ilişkin olarak kullanılması gereken araç gereçlere ve bu araç gereçlerin bütün öğrencilerin istifadesine sunulmasına dönük olarak yapılacaktır. Yazılı okuma levhaları, hesap cetvelleri, tartılar ve ölçekler, duvar haritaları ve koleksiyonlar öğrenci istifadesine sunulacak, ilkokul için bulundurulması gerek araç gereçlerin listesi Eğitim Bakanlığı İlköğretim Müdürlüğü tarafından oluşturulacaktır. İlkokul müfettişleri de okulları bu malzemelerin dikkatle korunup korumadıkları yönüyle teftiş edecek ve durumu Valilik ve Eğitim Bakanlığı'na rapor edeceklerdir.

Okul kütüphanelerine yönelik teftişte müfettişler, öğretmenlerin ve fakir öğrencilerin istifadesine sunulmak yönüyle teftiş yapacak ve ilkokul müfettişleri, kütüphanelerin iyi korunup korunmadığını denetleyecektir.

5. Öğretime yönelik teftişte ilkokul müfettişleri, öğretimin verilmesi gerek programa uygunluğu yönünden teftiş yapacak ve öğrencilerin öğrenme düzeyini 
inceleyeceklerdir. Bunun akabinde öğretmenlere gerekli rehberlik yapılacak ve ayrıca öğretmenlere yönelik ders yönetimi ve anlatım konusunda konferanslar vereceklerdir. İkinci teftişte öğretmenin kendisine yapılan rehberliğe uygun davranmadığının görülmesi ya da öğretmenin yetersizliği durumunda hemen il eğitim müfettişliği bilgilendirilecektir. Teftiş sırasında meşrutiyetin ve Osmanlı olmanın gereklerin yerine getiriliyor olmasına özellikle dikkat edilecektir. İlkokullarda Büyük Eğitim Meclisi’nin tasvip etmediği ve yasakladığg hiçbir kitap okutulmayacaktır.

Okulların sağlık açısından durumuna dönük teftişe gelince, esas olarak ilkokulların sağlık açısından teftiş edilme görevi vali ya da kaymakam tarafından görevlendirilecek tıp müfettişine aittir. Fakat ilkokul müfettişleri bu görevde tıp müfettişleri ile ortak sorumlulukta olup Eğitim Bakanlığı bünyesinde oluşturulmuş olan Çocuk Sağlığı Koruma Kurulu'nun talimatına uygun olarak teftiş yaparlar. Bu konudaki raporlarını görev yaptıkları yerin en büyük mülki amirine verirler. Ayrıca müfettişler, okulların temizliğine ve öğrencilerin temizlik açısında durumlarına da bakarlar.

Özel okulların teftişine gelince, müfettişler bu okulları öğretim mevzuatına ve Osmanlılık şanına yaraşırlık açısından teftiş edeceklerdir. Teftiş sırasına buna aykırı bir durumun ve öğretmenlerin diplomalarının Eğitim Bakanlığı'nca onaysız olduğunun görülmesi halinde durum, derhal Valiliğe ve Eğitim Bakanlığı'na bildirilecektir. Eğitim Bakanlığı tarafından okutulması yasaklanmış bir kitap bulunması halinde de durum, derhal, valiliğe bildirilecek ve ilgili kitaba el konacaktır. Bu emirlerin inceleme-soruşturma ile ilgili olan ve yasak hükümlerine aykırı durumlar olması durumunda rapor en geç iki ay içerisinde Eğitim Bakanlığı'na bildirilecektir. 
İlkokul müfettişlerinin görevleri arasında tavsiye de vardır. İlkokul Müfettişleri köy ve kasabaları gezerken halka eğitim ve öğretim konularında tavsiyede bulunacaklardır. Bundan hareketle ilköğretim müfettişlerinin görev tanımı içinde halkı bilgilendirmek ve halkla ilişkiler olduğu ve müfettişler aracılığıyla bir bilinçlendirme yapılmasının olduğu anlaşılmaktadır.

Sonuç olarak, kamu eliyle yürütülen bir toplumsal işlev olan eğitimin denetime ilişkin özgün bir yapı dikkat çekmektedir. Osmanlı Dönemi’nde işlevi fark edilmiş olan eğitim denetiminin, Cumhuriyet Döneminde de öneminin artarak devam ettiği, bu nedenle de önemli yasal metinlere konu olduğu görülmektedir. Bu metinlerden 1911 tarihli talimatname belki de Osmanlı Dönemi’nde eğitim denetimi ile ilgili en açık hukuki metindir.

\section{Cumhuriyet Döneminde Son Düzenlemeler, Tartışma ve Sonuç}

16 Ağustos 1997 tarihine kadar olan süreçte Türkiye'de eğitim yapılanmasına genel olarak bakıldığında eğitim basamaklarının süresi 5 yıl olan ilkokul, süresi 3 yıl olan ortaokul ve yine süresi 3 yıl olan liseden oluştuğu görülmektedir. 16 Ağustos 1997 tarihinde, 1739 sayılı Milli Eğitim Kanunu'nda yapılan değişiklikle ilkokul ve ortaokullar birleştirilerek kesintisiz eğitimin verildiği 8 yıl süreli ilköğretim okulları ihdas edilmiş, orta öğretim kurumlarının sürelerinde ise bir değişikliğe gidilmemiştir. Yine 30 Mart 2012 tarihinde aynı kanunun 24. maddesinde bir değişiklik yapılmış ve ilköğretim okulları süreleri 4 yıl olan ilkokul ve ortaokul olarak ayrıştırılmış ve yine ortaöğretim kurumları da süreleri 4 yıl olarak zorunlu hale getirilmiştir.

Günümüzde eğitim teftişi iki biçimde yürütülmektedir. Birincisi 5018 sayılı Kamu Mali Yönetimi ve Kontrol Kanunu'na göre MEB İç Denetim Birimi Başkanlığı'dır. İlgili

Kanunun 63. Maddesinde "İç denetim, kamu idaresinin çalışmalarına değer katmak ve 
geliştirmek için kaynakların ekonomiklik, etkililik ve verimlilik esaslarına göre yönetilip yönetilmediğini değerlendirmek ve rehberlik yapmak amacıyla yapılan bağımsız, nesnel güvence sağlama ve danışmanlık faaliyetidir. Bu faaliyetler, idarelerin yönetim ve kontrol yapıları ile malî işlemlerinin risk yönetimi, yönetim ve kontrol süreçlerinin etkinliğini değerlendirmek ve geliştirmek yönünde sistematik, sürekli ve disiplinli bir yaklaşımla ve genel kabul görmüş standartlara uygun olarak gerçekleştirilir. İç denetim, iç denetçiler tarafından yapılır. Kamu idarelerinin yapısı ve personel sayısı dikkate alınmak suretiyle, İç Denetim Koordinasyon Kurulu'nun uygun görüşü üzerine, doğrudan üst yöneticiye bağl1 iç denetim birimi başkanlıkları kurulabilir." denmektedir. İkinci teftiş birimi ise 652 sayılı kanun hükmünde kararname ile kurulan Rehberlik ve Denetim Birimi Başkanlığı'dır. Bu başkanlığa bağlı Maarif Müfettişleri illerde bulunan kurumların rehberlik, denetim, araştırma, inceleme ve soruşturma hizmetlerini planlamak ve yürütmekten sorumludurlar.

1911 tarihli İlkokul Müfettişlerinin Görevlerine Dair Talimat'a göre eğitim müfettişlerinin üç temel görevi vardır. Bunlar; teftiş, soruşturma ve tavsiyedir. Teftiş, okul ve eğitim denetimini ifade etmektedir. Bursalıoğlu'na (2002) göre eğitim teftişi, eğitimde izleme ve gözlem yollarından biridir. Teftiş, kamu otoritesi ve yararı adına bireysel ve örgütsel davranışı kontrol etme süreci olup, bir düzenleyici mekanizmadır. Teftiş, gereklidir. Bunun nedeni önleyici ve düzeltici etkinliklerin önlemlerin örgüt içinde uyumu sağlamada temel işlev olmalarıdır. Kurum teftişleri açısından bakıldığında, maarif müfettişlerinin taşrada bulunan, yükseköğretim kurumları hariç, tüm okul ve kurumların teftişini yapmaya yetkili oldukları anlaşılmaktadır. 2011 tarihli 652 sayılı kanun hükmünde kararnamemin 17. Maddesi adı Maarif Müfettişleri olarak değiştirilen Eğitim Müfettişlerinin bağlı olduğu Rehberlik ve Denetim Başkanlığının görevleri belirtilmektedir (MEB, 2011). Buna göre; Bakanlığın görev alanına giren konularda Bakanlık personeline, Bakanlık okul ve kurumlarına, özel öğretim 
kurumlarına ve gerçek ve tüzel kişilere rehberlik edilmeli; Bakanlığın görev alanına giren konularda faaliyet gösteren kamu kurum ve kuruluşları, gerçek ve tüzel kişiler ile gönüllü kuruluşlara, faaliyetlerinde yol gösterecek plan ve programlar oluşturmak ve rehberlik etmek gerekmektedir. Bakanlık tarafından veya Bakanlığın denetiminde sunulan hizmetlerin kontrol ve denetimini ilgili birimlerle iş birliği içinde yapmak, süreç ve sonuçlarını mevzuata, önceden belirlenmiş amaç ve hedeflere, performans ölçütlerine ve kalite standartlarına göre analiz etmek, karşılaştırmak ve ölçmek, kanıtlara dayalı olarak değerlendirmek, elde edilen sonuçları rapor hâline getirerek ilgili birimlere ve kişilere iletmek görevi vardır. Bakanlık teşkilatı ve personeli ile Bakanlığın denetimi altındaki her türlü kuruluşun faaliyet ve işlemlerine ilişkin olarak, usulsüzlükleri önleyici, eğitici ve rehberlik yaklaşımını ön plana çıkaran bir anlayışla, Bakanlığın görev ve yetkileri çerçevesinde denetim, inceleme ve soruşturma iş ve işlemleri Maarif Müfettişleri aracılığıyla yapılmalıdır. Bunların yanı sıra her derece ve türdeki örgün ve yaygın eğitim kurumları ile il ve ilçe millî eğitim müdürlüklerinin rehberlik, işbaşında yetiştirme, denetim, değerlendirme, inceleme, araştırma ve soruşturma hizmetleri Maarif müfettişleri tarafından yürütülecektir. Yine 652 sayılı kanun hükmünde kararnameye dayalı olarak çıkarılan Millî Eğitim Bakanlığı Rehberlik ve Denetim Başkanlığı İle Maarif Müfettişleri Başkanlıkları Yönetmeliği’nin 46. Maddesinde de Maarif müfettişleri başkanlığının görevleri ilgili yasaya paralel olarak belirtilmektedir (MEB, 2011). Bu yargılardan hareketle 1911 yılından günümüze gelindiğinde, teftiş kavramının kontrol ve izleme odaklı olarak yürütülen bir faaliyetten, rehberlik ve geliştirme odaklı bir faaliyete doğru yön değiştirdiği savunulabilir.

Yine 1911 tarihli İlkokul Müfettişlerinin Görevlerine Dair Talimat'a göre eğitim müfettişlerinin üç temel görevinin ikincisi soruşturmadır. Soruşturma eğitim ve eğitimciler hakkındaki iddiaların araştırılmasını ve gerekirse tecziye edilme tekliflerini ifade etmektedir. 
Soruşturma işlevi doğrudan müfettişlerle ilgili bir eylemdir. Su’ya (1974) göre denetim bir yönüyle örgüt içinde meydana gelen disiplin ve yasadışı olayların soruşturma ve incelemelerinin yapılarak sonucun üst ve ilgili kademelere bildirilmesini de içine almaktadır. Tahkikat olarak adlandırılan soruşturma işlevi, 1911 tarihli talimatnamede yer aldığ gibi halen günümüz güncel mevzuatında da yerini, olduğu gibi korumaktadır.

Müfettişlerin üçüncü görevi olan tavsiye ise halkın eğitim konusunda bilinçlendirilmesini içermektedir. Günümüzdeki yasal düzenlemelere bakıldığında aynı hususların kimi değişikliklerle birlikte halen devam ettirildiği anlaşılmaktadır. Buna göre İlkokul Müfettişleri köy ve kasabaları gezerken halka eğitim ve öğretim konularında tavsiyede bulunacaklardır. Bundan hareketle ilköğretim müfettişlerinin görev tanımı içinde yetişkin eğitimi ve halkla ilişkiler olduğu ve müfettişler aracılığıyla bir bilinçlendirme yapılmasının olduğu anlaşılmaktadır. Halen günümüzde geçerli 222 sayılı İlköğretim ve Eğitim Kanunu'nun 52 ve 53. Maddelerine bakıldığında müfettişlerin görevleri arasında “...ilköğretim müfettişleri ilköğrenim çağındaki çocukların mecburi ilköğretim kurumlarına devamlarını sağlamakla veli yahut vasi veya aile başkanlarına ve okul idarelerine yardımla ve her türlü tedbiri almakla vazifelidirler. Okula devam etmeyen öğrencilerin devamsızlık sebepleri okul idarelerince ve ilköğretim müfettişlerince araştırılarak devama engel olan maddi ve manevi sebeplerin giderilmesine çalışılır.” hükümleri sayılmaktadır. Bu hükümlerden hareketle 1911 tarihli talimatnameden biraz farklı olarak müfettişlerin halen doğrudan halk ile ilgili faaliyetler içerisinde olmaları gerektiği anlaşılmaktadır. Taşdemir (2016) buna ek olarak müfettişlerin eğitim çalışanlarını geliştirme yönünde bir çaba içinde olduklarını da belirtmektedir.

Yukarıda belirtilen belgede en çok dikkat çeken hususlardan biri de müfettişlerin görevleri arasında öğretim faaliyetinin programa uygun yürütülmesinin sağlanmasıdır. Bu 
durum öğretim programlarının tarihçesine 1şık tutucu mahiyettedir. Zira çağdaş program geliştirme kitaplarında program geliştirme sürecinin tarihçesine vurgu yapılırken en erken tarihler olarak 1920'li yıllar anılmaktadır (Akpunar, 2015). Oysa yukarıdaki belge 1910/1911 tarihli olmasına karşın açıkça öğretim programından ve müfettişlerin programın uygulanmasını takip etmesinden söz etmektedir. Yine 1 Nisan 1895, 3 Haziran 1901 ve 20 Ekim 1904 tarihli başka belgelerde de ilkokul müfettişlerinin ve yöneticilerin görevlerinin atandıkları okulların devir, teftiş ile öğretim faaliyetlerinin emir ve programlara uygun yürütülmesini sağlamak olduğu vurgulanmaktadır (Özmen, Açıkses, Usta ve Uluerler, 2014).

Günümüz eğitim denetimi mevzuatı ile Osmanlı Dönemi mevzuatı karşılaştırıldığında en önemli farkın müfettişlerin atanma biçimleri ile alanda geliştirilmiş standart form ve raporların kullanımında olduğu görülmektedir. Ayrıca son yıllarda teftiş sisteminde çok sık meydana gelen değişikliklerden hareketle, yaklaşık yüzeli yıllık geçmişine rağmen halen iyi bir teftiş sistemi oluşturamadığımız anlaşılmaktadır. Nitekim 2011 yılında çıkarılan 652 sayılı kanun hükmünde kararname ile Bakanlık merkez teşkilatında bulunan bakanlık müfettişleri ile taşrada görev yapan maarif müfettişleri birleştirilmiş ve tüm müfettişler taşrada yer alan il milli eğitim müdürlükleri bünyesinde kurulan eğitim denetmenleri başkanlığı çatısı altına alınmışlardır. Ancak uygulamadaki kimi sorunlar nedeniyle 2016 haziran ayında Meclis'e sunulan maarif kanunu taslağında tüm eğitim denetmenlerinin uzman kadrosuna atanarak sadece Bakanlık merkez teşkilatında ihtiyaç duyulduğu kadar müfettiş istihdamı yönünde bir eğilim belirmiştir. Oysa bu eğilim Su tarafından daha 1974 yılında taşrada bulunan müfettişlerin mahalli otoriteden kurtarılması amacıyla Bakanlık merkezine bağlanması önerisiyle dile getirilmiştir (Yalçınkaya, 1990). Bundan hareketle eğitim teftişi sisteminde köklü ve yapısal bir felsefe bulunmadığı, eğitim teftişi politikalarının gündelik tartışma ve eğilimlerden etkilendiği sonucuna varmak mümkündür. 
1911 y1lından günümüze gelindiğinde en önemli değişimin eğitim müfettişlerinin seçilme ve atanma biçiminde olduğu değerlendirilebilir. Zira Osmanlı Türkiye'sinde eğitim müfettişlerinin vaizlerden müderrislere, okuma yazma bilen sıradan memurlardan tren kondüktörlerine kadar farklı mesleklere mensup kişilerden atandıkları anlaşılmaktadır (Özmen, Açıkses, Usta ve Uluerler, 2014). Oysa günümüzde bu prosedür büyük ölçüde şeffaf, ilana dayalı, eğitim fakültesi ya da benzeri dört yıllık bir fakülte mezunu olanlar arasından yapılan seçmelerle yapılmaktadır. 02/12/2016 tarih ve 6764 sayılı Kanun Hükmünde Kararname ile İl Milli Eğitim Müdürlükleri bünyesinde kurulu bulunan Maarif Müfettişleri Başkanlıkları lağvedilmiştir. Bunun yerine tamamı merkezde yer alan Bakanlık Maarif Müfettişleri ve Bakanlık Maarif Müfettiş Yardımcılarından oluşan Teftiş Kurulu Başkanlığı oluşturulmuştur.

\section{Makalenin Bilimdeki Konumu (Yeri)}

Eğitim Bilimleri Bölümü, Eğitim Yönetimi ve Teftişi Anabilim Dalı

\section{Makalenin Bilimdeki Özgünlüğü}

“1910/1911 Tarihli İlkokul Müfettişlerinin Görevlerine Dair Yönerge’nin Günümüz İtibariyle Yapılan Okul Teftişi İle Karşılaştırılması” adlı çalışma ile bir eğitim yönetimi kitap ya da makalesinde, aslı daha önce yayınlandığı tespit edilememiş bir belgeyi gün yüzüne çıkararak günümüzdeki durum çerçevesinde tartışılması sağlanmıştır. İlgili çalışma, eğitim teftişinde, yaklaşık yüz yıllık bir süreçte meydana gelen değişimi, önemli hususlara değinerek gözler önüne sermektedir. Bu makale ayrıca, günümüzdeki durum ile Osmanlı İmparatorluğu Dönemi'ndeki durumun ele alınması itibariyle, eğitimbilimleri ile tarih disiplinlerini buluşturmak suretiyle disiplinler arası bir çalışma niteliğine sahiptir. Ayrıca çalışmada yapılan tartışmanın günümüzde eğitim teftişine dair yapılacak düzenlemelere katkı sağlayacağı umulmaktadır. 


\section{KAYNAKÇA}

Akpunar, B. (2015). Eğitimde Program Geliştirme. Ankara: Data.

Aydın, M. (2014). Çăğdaş Ĕ̆itim Denetimi (6. Baskı). Ankara:PegemA.

Başaran, İ. E. (2000). Eğitim Yönetimi. Ankara: Ferya.

Buluç, B. (2008). Türk Eğitim Sisteminde Teftiş ve Denetim Alt Sisteminin Gelişim Süreci. Bilgi Çă̆ında Ĕ̆itim, 4 (27-30).

Bursalığlu, Z. (2002). Okul Yönetiminde Yeni Yapı ve Davranış. Ankara: Pegem A.

Hesapçığlu, M. (1989). Ĕgitim Planlaması ve Yönetimi. İstanbul: Marmara Üniversitesi Yayınları.

Hesapçıŏlu, M. (1994). Insan Kaynakları Yönetimi ve Ekonomisi. İstanbul: Beta.

http://rdb.meb.gov.tr/www/turk-egitim-sisteminde-rehberlik-ve-denetimin-tarihselgelisimi/icerik/9

http://www.resmigazete.gov.tr/eskiler/2011/09/20110914-1.htm

Karasar, N. (1997). Bilimsel Araştırma Yöntemi(9. Baskı). Ankara: Nobel Yayın Dağıtım.

Öz, M. F. (2003). Türkiye Cumhuriyeti Milli Eğitim Sisteminde Teftiş. Eskişehir: Osmangazi Üniversitesi.

Özalp, İ., Koparal, C., ve Berberoğlu, G. (2000). Yönetim ve Organizasyon. Eskişehir: AÖF Yayınları.

Öz-Alp, Ş., Timur, N., Koçel, T., Geylan, R., ve Odabaşı, Y., (1996). Genel İşletme. Eskişehir: Açık Öğretim Fakültesi Yayınları.

Özmen, F., Açıkses, E., Usta, M. E., Uluerler, S. (2014). Meşrutiyetin İlanından, Cumhuriyet Dönemine, Osmanlı Devleti'nde Ë̆itim Denetimi (1876-1923). Frrat Üniversitesi Destekli Araştırma Projesi (FÜBAP), Elazı̆g. 
Su, K. (1974). Türk Ĕgitim Sisteminde Teftişsin Yeri ve Önemi. Ankara: Milli Eğitim Basımevi.

Şahin, S. Elçiçek, Z. ve Tösten, R. (2013). Türk Eğitim Sisteminde Teftişin Tarihsel Gelişimi ve $\mathrm{Bu}$ Gelişim Süreci İçerisindeki Sorunlar. TheJournal of $\begin{array}{lllll}\text { AcademicSocialScienceStudies. } & 6 & \text { (5), 1105-1126. doi: }\end{array}$ http://dx.doi.org/10.9761/JASSS1336.

Taşdemir, A. (2016) . Denetmen ve Öğretmen Görüşlerine Göre İl Ĕ̈itim Denetmenlerinin Rollerini Gerçekleştirme Düzeyleri (Yayımlanmamış Yüksek Lisans Tezi). Şanlıurfa: Harran Üniversitesi Sosyal Bilimler Enstitüsü.

Taymaz, H. (2010). Eğitim Sisteminde Teftiş (7. Baskı). Ankara: PegemA.

Yalçınkaya, M. (1990). Türk Eğitim Sisteminde Teftişin Bütünleştirilmesi. Ankara Üniversitesi Eğitim Bilimleri Fakültesi Dergisi. 23 (1), 246-267. doi: 10.1501/Egifak_0000000845.

Yıldırım, A. \& Şimşek, H. (2008). Sosyal Bilimlerde Nitel Araştırma Yöntemleri (6. Baskı). Ankara: Seçkin. 


\section{Summary}

Purpose and Significance: Inspection can be described as a duration of checking whether or not employees have implemented what they are expected to do properly. Inspectors are also responsible for bad behaviors (such as bullying) at work environment (Taymaz, 2010, p.3). Inspection of schools is provided to aid them perform effectively. Effectiveness rate of a school is dependent on to which degree it can fulfill the targets and expectations. Indeed, a school inspection is not only carried out by inspectors but also it can be processed by school managers and higher ranking managers as well. During a school inspection, it can be beter to tolerate school administrators' freedom to produce some space for their creativity. Beside that inspectors should be careful about valuing all staff at some level. Staff should be aware of inspection and he/she must be open for cooperation and communication. Inspectors should have leadership skills to manage an inspection process. Audit should be well-planned before so that any staff could have some opportunity to present value of their work (Başaran, 2000, p. 137). Main goal of an inspection should be development of an organization. That is why by comparing similarities and differences between Ottoman period inspection and modern inspection in Turkey, any transformation that can lead to further development can be derived. Methodology: Documentary analysis method was used for his study. This method aims to display historical and current realities as they are. Documentary analysis is about extrapolating and finding relations between written things by using historical and recent documents. Historical data are accepted as this method's study area. Beside historical documents, archeological heritages are also conceived as sources to analyse (Karasar, 1999).

Results: Audit of education draws our attention by its novel structure that is implemented by state organizations performing a social function. Importance of educational inspection has been recognized by both Ottoman State and Turkish Republic and found its place in 
constitution. 1911 dated regulation document can be accepted as the unequivocable one that sheds light on late Ottoman period. From that document, it can be understood that inspectors for primary schools had three main duties: inspection, interrogation, and advice. Inspection involves inspection while interrogation is investigation of complaints about educators. Advice includes raising awareness of people about education. When current regulations are analysed, similar role of educational inspectors seem to continue with enriched roles and content.

Discussion and Conclusion: Main difference between Ottoman time inspection legislation and current legislation appears to be about recruitment of inspectors and standardized inspection forms (checklists) and reports. Since, active legislation at the present time is more comprehensive than late Ottoman period. Because it can be concluded that amount of knowledge in education sciences and development of new methods in inspectorate results that inclusiveness. Expansion in the content of educational sciences might have produced need for more detailed inspection. Expectations from inspections regarding the legislations in 1910-11 and today show similarities in essence, however more structured regulations of current inspectorate may point to the enhanced understanding of how inspection should take place.

Keywords: Inspection, Educational Inspection, Educational Inspectors, History of Inspection. 
EK A

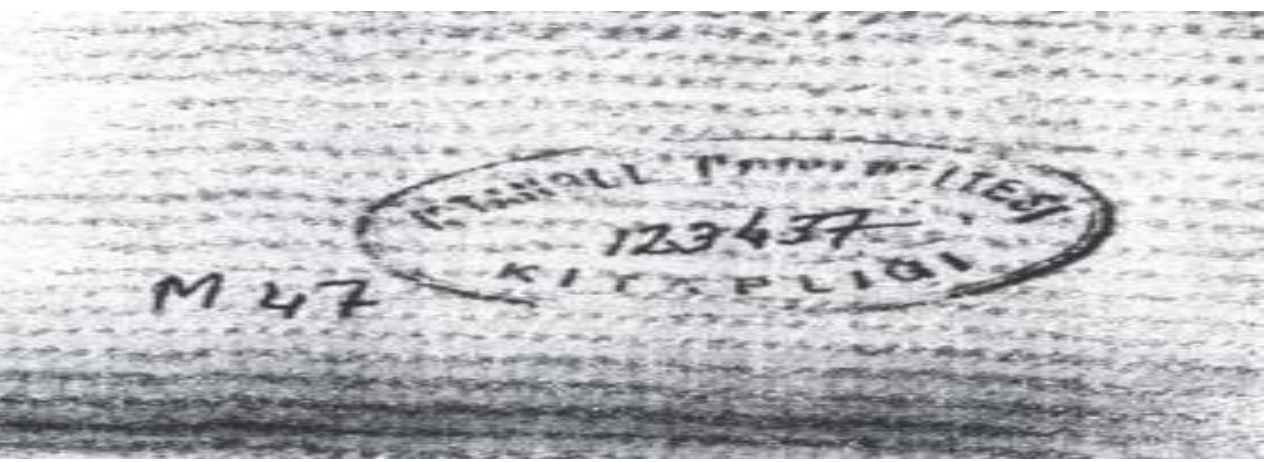

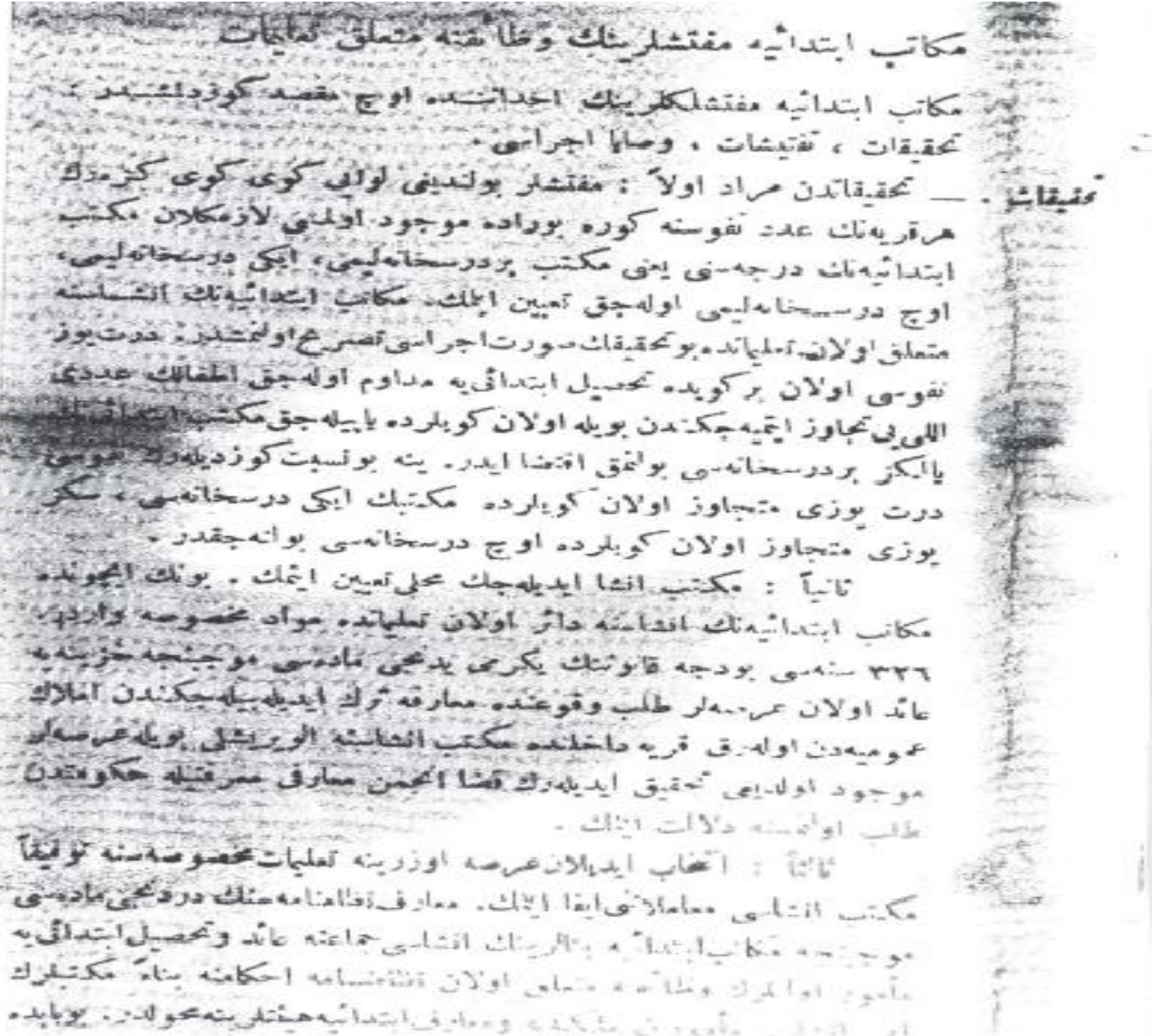




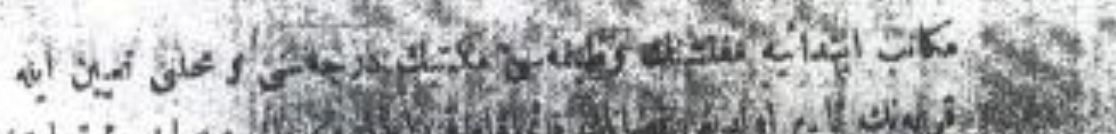

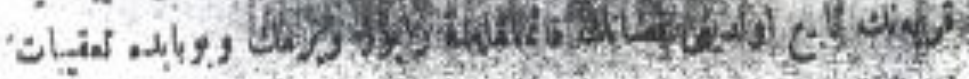

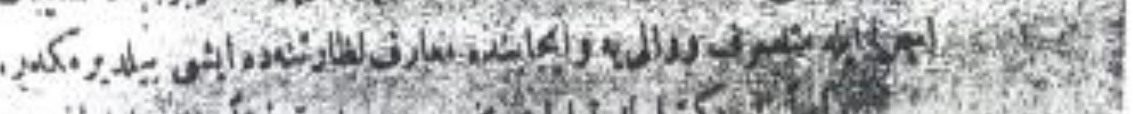

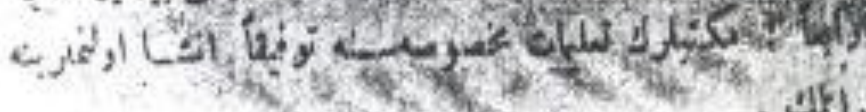

나. 310

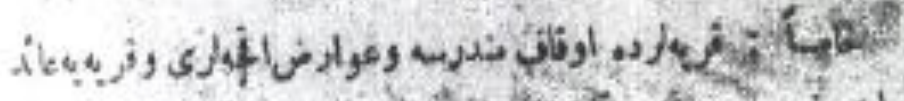

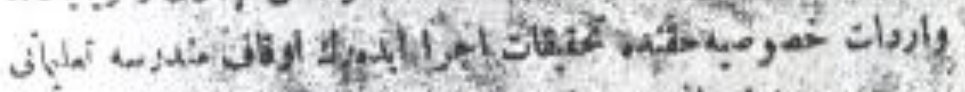

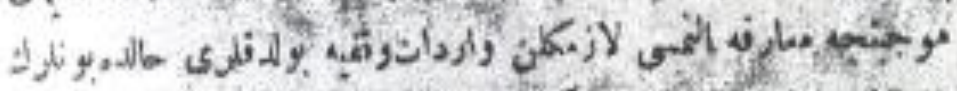

.

ن

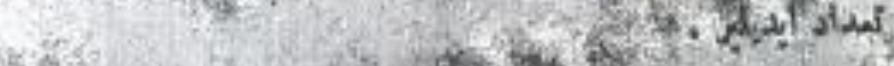

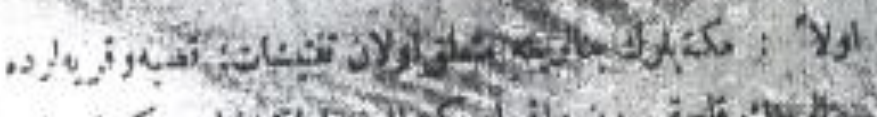

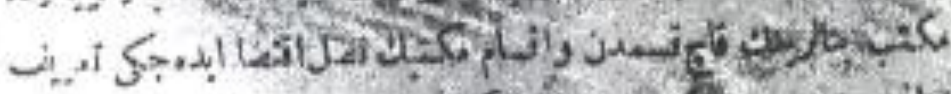

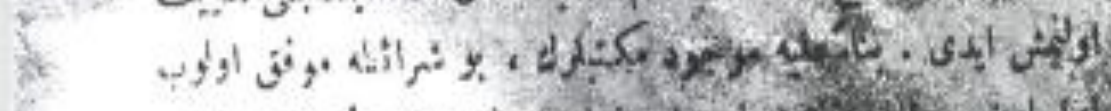

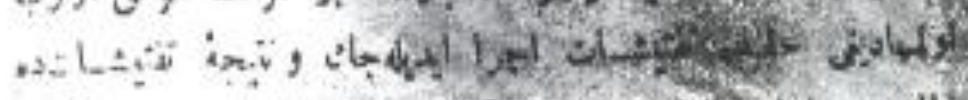
(6.

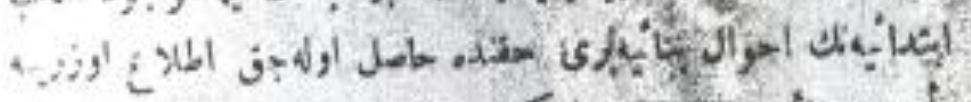

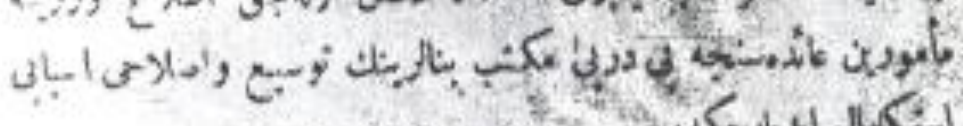

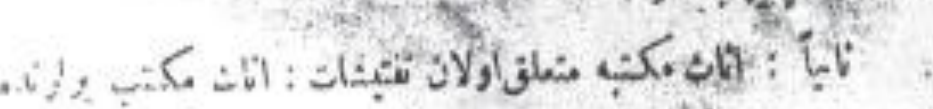

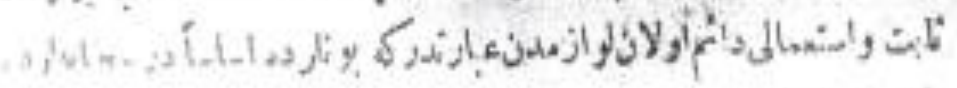

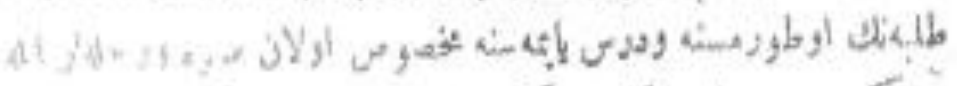

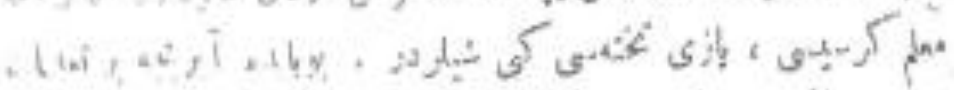

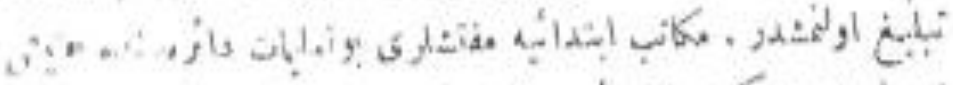

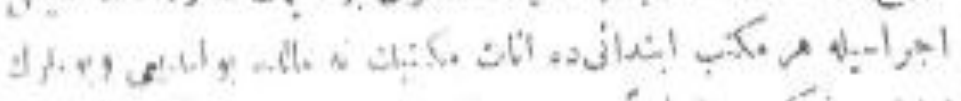
بأ

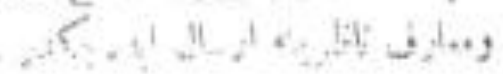




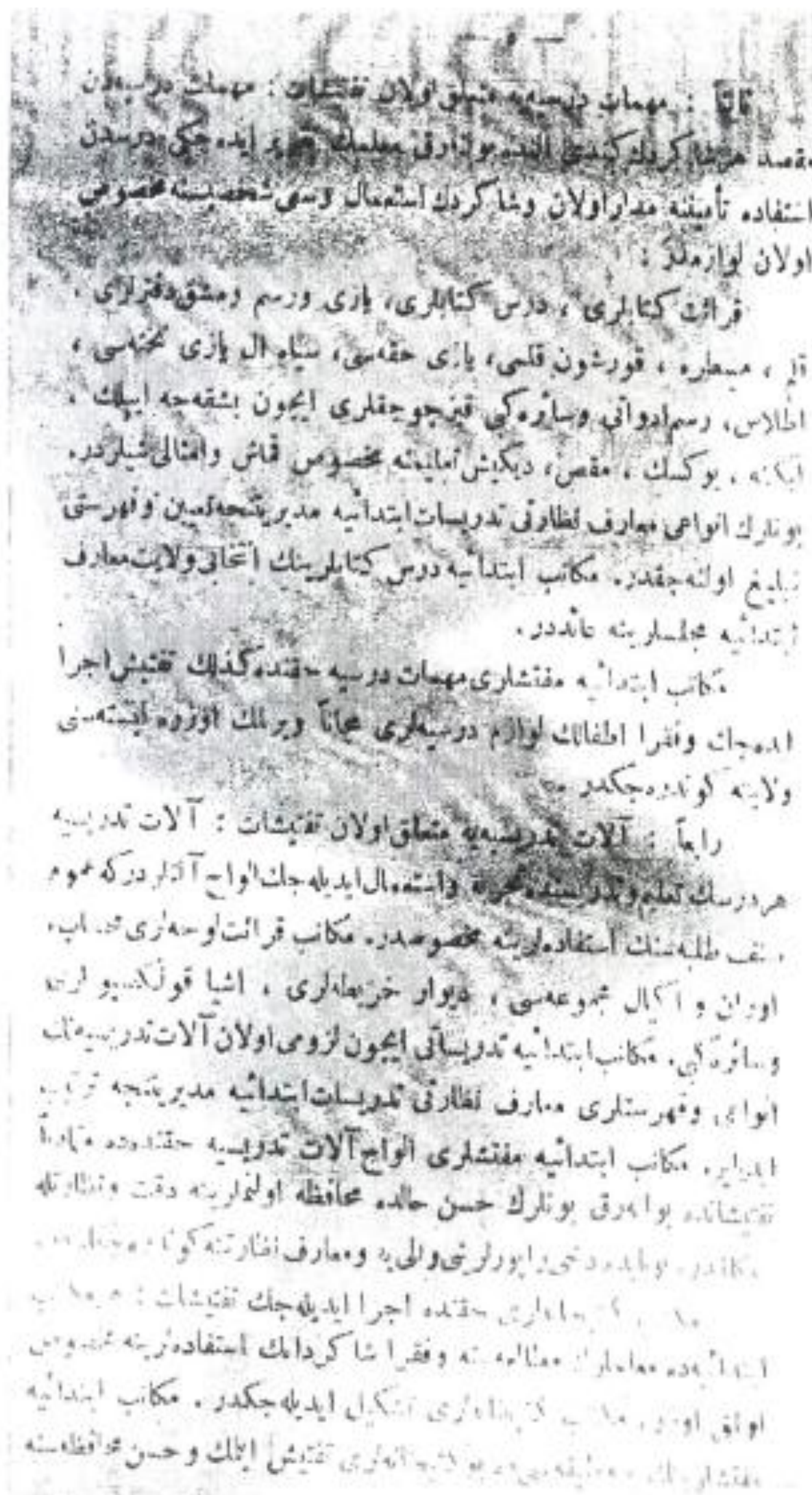




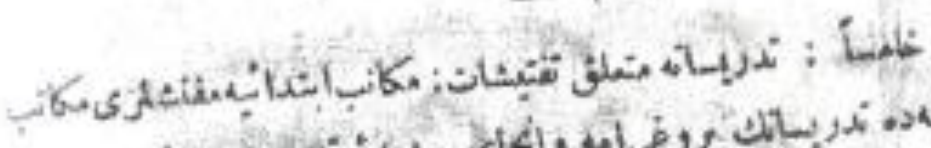
然

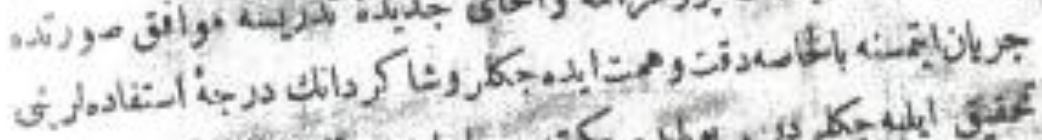

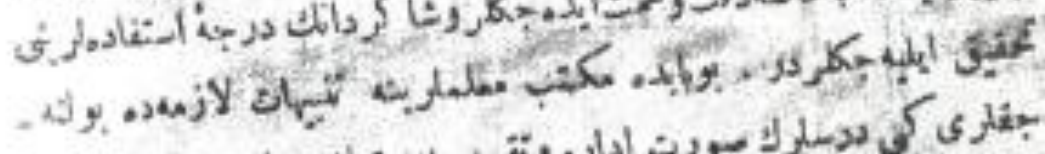

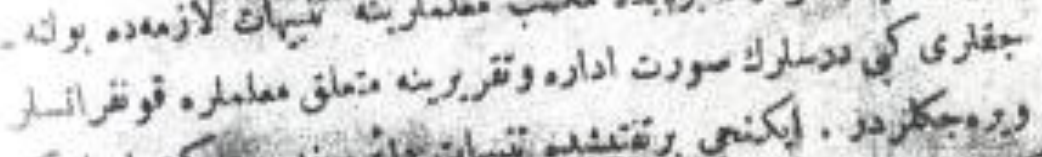

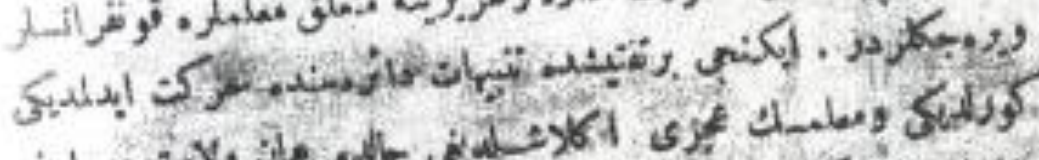

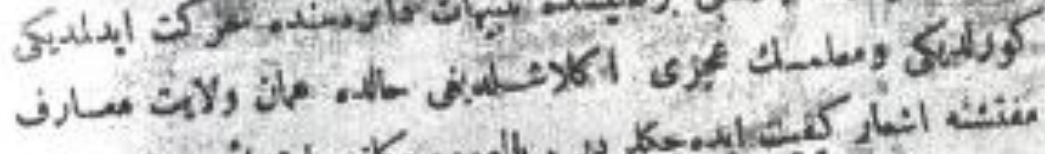

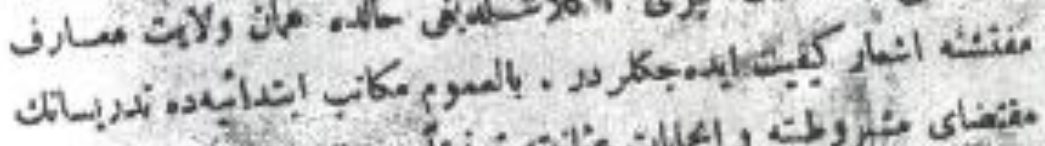

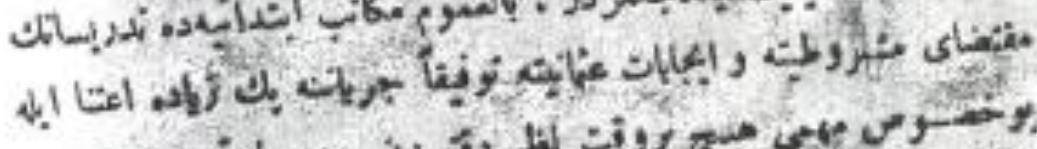
.

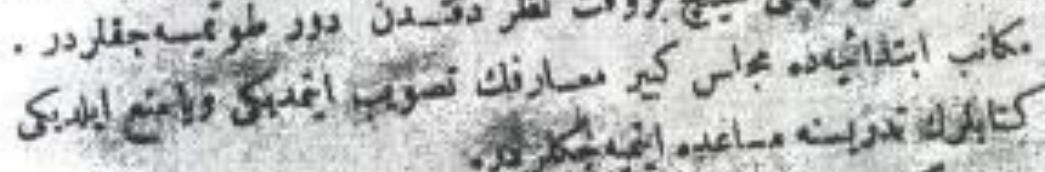

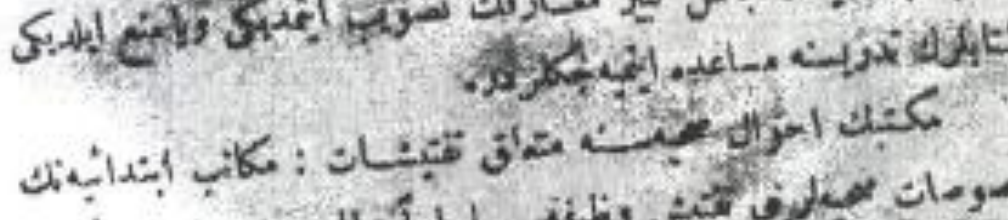

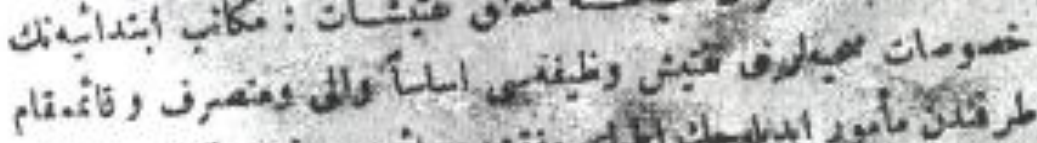

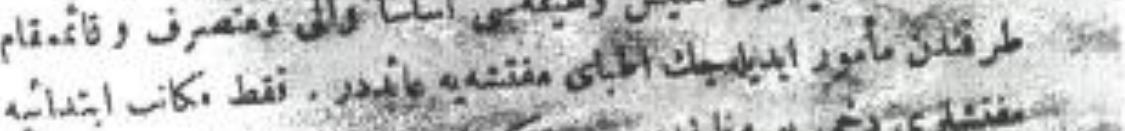

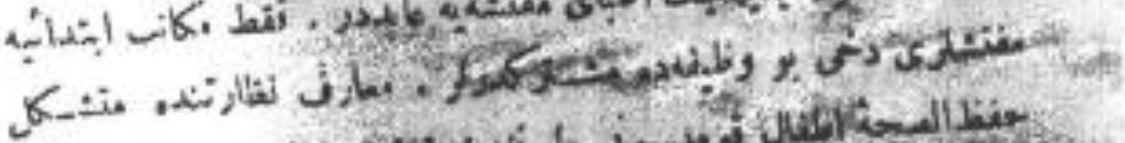

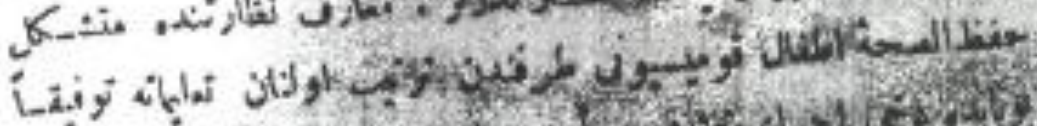

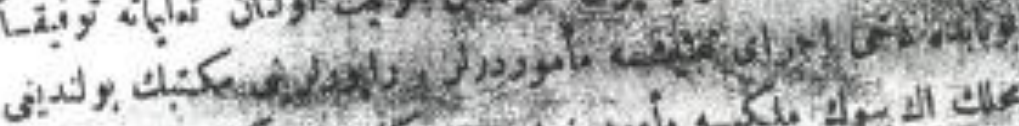

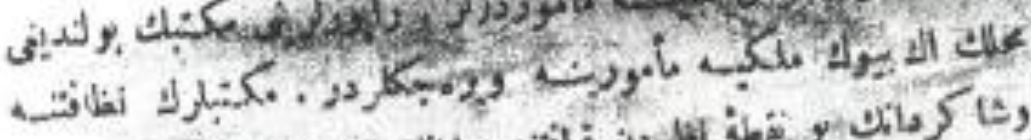

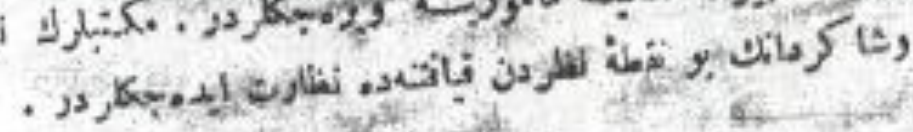

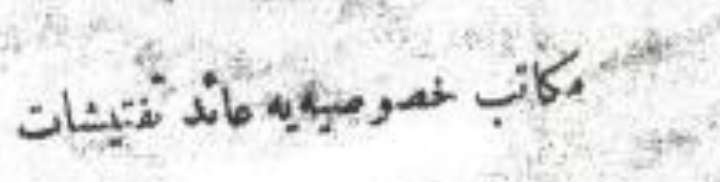

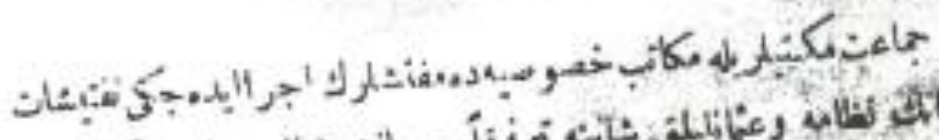
.

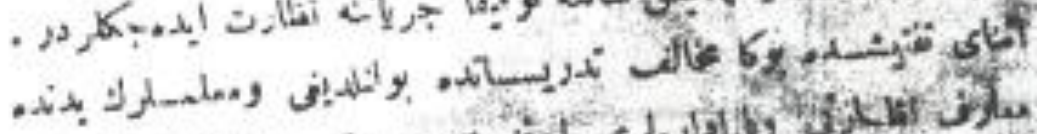

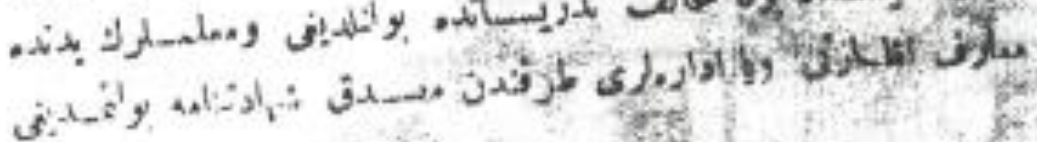

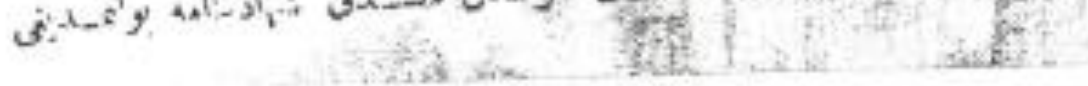




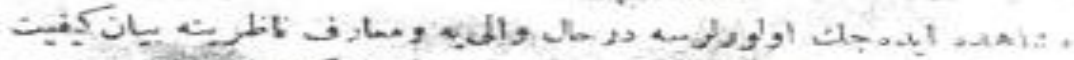

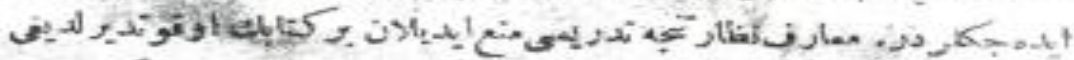

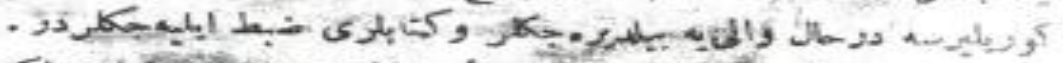
Si

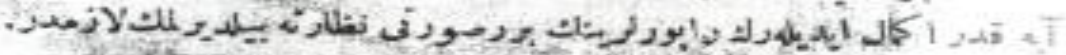

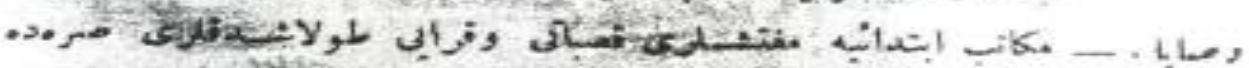

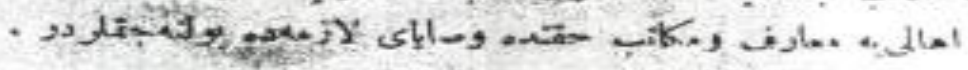

$\rightarrow$ entisit:

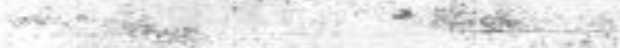

$\sin 20 x+\cdots$ 